\title{
Sunflower Meal and Supplementation of an Enzyme Complex in Layer Diets
}

http://dx.doi.org/10.1590/1516-635x1703363-370

\section{-Author(s)}

Araújo WAG

Albino LFT"

Rostagno HS

Pessoa GBS"II

Cruz SCS"II

Lelis GR"I'

Carneiro PRO"I

Vieira RA"I

Federal Institute of Education, Science and Technology of Northern Minas Gerais.

" Department of Animal Science/ UFV.

III Doctorate Program, DZO/ UFV.

Project financed by FAPEMIG.

\section{nMail Address}

Corresponding author e-mail address Wagner Azis Garcia de Araújo

Rua Itagiba de Oliveira, $n^{\circ} 317$, Muriaé, MG, Brazil. Zip code: 36880-000.

E-mail: aziszoo@yahoo.com.br

\section{EKeywords}

Alternative feedstuffs, eggs quality, feed costs, poultry.

\section{ABSTRACT}

The objective of this experiment was to evaluate the performance of 64- to 79-wk-old laying hens fed diets supplemented with an enzyme complex (EC) and containing increasing sunflower meal (SFM) levels. A total of $384 \mathrm{Hy}$-Line Brown layers were distributed according to a randomized block design in a $4 \times 2$ factorial arrangement (four levels of SFM, and inclusion or not of EC), with eight replicates of six birds each unit. The levels of SFM inclusion were 0, 8, 16 and 24\%, utilized in two distinct diets. Diets were calculated to meet all the nutritional requirements of birds, except for the nutrients that would be made available by the nutritional matrix of the enzyme complex, with or without utilization of EC. The parameters analyzed were feed intake (g/bird/day), egg production (\%/bird/day), egg weight, egg mass ( $\mathrm{g} /$ bird/day), feed conversion ratio per egg mass, feed conversion ratio per dozen eggs, body weight gain, egg components (yolk, albumen and eggshell) and the economic efficiency index (EEI). There was no interaction between EC addition and the SFM levels in the diet. The addition of EC in the diets of laying hens did not affect egg productive or components parameters. The increase in the SFM levels in the diet presented quadratic effect on egg production and feed conversion ratio per dozen eggs, with calculated optimal sunflower meal inclusion levels of $6.72 \%$ and $5.83 \%$, respectively, for each parameter. The best economic efficiency per dozen eggs was obtained with the diet with $16.0 \%$ SFM and EC inclusion, whereas per egg mass with the diet with of $24.0 \%$ SFM and no EC addition.

\section{INTRODUCTION}

Sunflower meal is a byproduct from the oil industry, but there are few studies on its inclusion in layers diets to date. Its high fiber content, of 45.19 neutral detergent fiber (NDF) and 21.35 acid detergent fiber (ADF) limits its inclusion of the meal in diets for those birds (NRC 1994; FEDNA 2003; INRA 2004). The utilization of exogenous enzymes could enhance fiber digestibility or phytic phosphorus solubilization in sunflower meal, thereby reducing the negative effects on layer performance.

Few studies on the inclusion of sunflower meal in diets for laying hens have been reported. Vieira et al. (1992) replaced all the soybean meal by sunflower meal (40.5\%) and added lysine in layers diets without compromising production parameters. However, feed conversion ratio $(F C R)$ and feed intake showed positive linear behavior as a function of the inclusion of sunflower meal in the diets (Vieira et al., 1992).

The genetic development in laying birds is dynamic, resulting in more productive and consequently more nutrient-requiring animals (Hy Line, 2009). Under this new scenario, it would be difficult to include such high inclusion levels of sunflower meal, such as those reported by Vieira et al. (1992), without compromising layer performance. Serman et al. (1997) verified that inclusion of sunflower meal in layer diets decreased 
feed intake, egg mass and weight gain. However, in that study, the diets did not contain synthetic amino acids, which may explain those results.

Studies found that it was possible to include up to $5.6 \%$ ground whole sunflower seeds in layer diets without affecting performance or egg quality (Tsuzuki et al., 2003). However, sunflower meal is a byproduct from the oil industry that contains less energy and higher fiber than the ground whole seed. Working with sunflower meal under partial oil extraction, Secoylu et al. (2004) included up to $20.0 \%$ in layer diets and did not observe any differences in egg mass or feed intake values.

Current studies have used lower addition levels of sunflower meal in the diets of laying hens. Up to $10 \%$ sunflower meal can be added to diets with the same protein content, but with the same energy content, without compromising intake, egg mass or egg quality parameters (Rezaei \& Hafezian 2007). Casartelli et al. (2006) reported that inclusion of up to $12.0 \%$ sunflower meal in layer feeds did not affect productive parameters or egg internal quality parameters. Additionally, the inclusion of sunflower meal in diets improved eggshell thickness. Recently, Junqueira et al. (2010), evaluating the economic viability of the inclusion of enzyme phytase and sunflower meal in layer diets, concluded that the addition of phytase reduced phosphorus excretion and improved the economic parameters. However, the maximum level of sunflower meal inclusion that did not negatively affect productive parameters was $4 \%$.

It is known that the higher the sunflower meal inclusion in the diets, the higher the inclusion of soybean meal as well, due to the low energy content of the material (Rezaei \& Hafezian 2007). Oil is one of the most expensive ingredients used in commercial layer feed formulation, and therefore, may significantly increase production costs. The objective of this study was to evaluate the effects of increasing levels of sunflower meal inclusion and the supplementation of an enzyme complex, containing carbohydrases and phytase, on egg production and economic parameters of layers from 64 to 79 weeks of age.

\section{MATERIAL AND METHODS}

The experiment was conducted between May and September 2011, in the facilities of the poultry sector of the Department of Animal Science of Universidade Federal de Viçosa, MG, Brazil. In total, $384 \mathrm{Hy}$ Line Brown layers in the second laying cycle, with $1.675 \pm 0.088 \mathrm{~g}$ body weight, were evaluated during the period of 64 to 79 weeks of age. Birds were distributed in a completely randomized design in a $4 \times 2$ factorial arrangement (diets with four sunflower meal inclusion levels and the addition or not of an enzyme complex), with eight replicates of six birds each.

Birds were housed in an open-sided masonry shed (5-m wide and 2-m high) with wire-mesh sides and covered with clay tiles. Layers remained in galvanizedwire cages, each divided in four $25 \times 45 \times 40 \mathrm{~cm}$ compartments, distributed in two tiers, and 0.80 $\mathrm{m}$ distant from the floor. Cages were equipped with galvanized-iron trough feeders and drinkers that covered the entire frontal extension of the cages.

Sunflower meal (SFM) was included in the diets at the levels of 0, 8, 16 and 24\%, and the enzyme complex was added at $0.005 \%$ or not (Table 1). The enzyme complex (carbohydrases and phytase) aimed at increasing the digestibility of substrates to the action of these enzymes. Dietes were formulated to supply the requirements recommended by Rostagno et al. (2005).

The chemical composition values applied for sunflower meal (Table 3) used for diet formulation were those analyzed in the laboratory of feed analysis of the Department of Animal Science of Universidade Federal de Viçosa, and the average values reported by several authors (NRC, 1994; FEDNA, 2003; INRA, 2004; Tavernari et al. 2010).

During the entire experimental period, house temperature inside was monitored daily (at $16 \mathrm{~h}$ ), using minimum-maximum thermometers. Birds received feed and water ad libitum and 16 hours of light per day during the entire experimental period, in compliance with the management recommendations of genetic company's manual. Eggs were collected twice daily (8 and 16 h), and egg-laying frequency and mortality were recorded. Birds and diets were weighed at the beginning and at the end of each 28-d period (from 64 to 71 weeks of age) to determine weight gain, feed intake, FCR per dozen eggs and FCR per egg mass.

The following performance parameters were evaluated: feed intake ( $\mathrm{g} / \mathrm{bird} /$ day), egg production (\%/bird/day), egg weight, egg mass (g/bird/day), FCR per egg mass, and FCR per dozen eggs. Eggs were collected on three last days, and six eggs per replicate were randomly selected per day to determine yolk, albumen and eggshell weights. The eggs per replicate and per day were individually identified and weighed on a scale of $0.001 \mathrm{~g}$ precision, and then broken. The yolk from each egg was weighed and the eggshell was washed and air-dried to obtain the weight of the eggshell without the internal membrane. The albumen weight was calculated as the difference between egg weight and yolk and eggshell weights. 
Table 1 - Percentage and chemical composition of the experimental (on "as-fed" basis) containing different sunflower meal inclusion levels and supplemented or not with the enzyme complex (EC)

\begin{tabular}{|c|c|c|c|c|c|c|c|c|}
\hline \multirow[b]{2}{*}{ Ingredients (\%) } & \multicolumn{4}{|c|}{ Without EC } & \multicolumn{4}{|c|}{ With EC } \\
\hline & $0 \%$ & $8 \%$ & $16 \%$ & $24 \%$ & $0 \%$ & $8 \%$ & $16 \%$ & $24 \%$ \\
\hline Corn & 62.560 & 56.707 & 51.193 & 45.091 & 62.557 & 56.704 & 51.190 & 45.088 \\
\hline Soybean meal & 24.154 & 20.739 & 17.019 & 13.803 & 24.152 & 20.737 & 17.016 & 13.801 \\
\hline Sunflower meal & 0.000 & 8.000 & 16.000 & 24.000 & 0.000 & 8.000 & 16.000 & 24.000 \\
\hline Soybean oil & 2.053 & 3.364 & 4.610 & 5.960 & 2.053 & 3.364 & 4.610 & 5.960 \\
\hline Dicalcium phosphate & 1.338 & 1.336 & 1.335 & 1.332 & 1.338 & 1.336 & 1.335 & 1.332 \\
\hline Limestone & 8.895 & 8.857 & 8.820 & 8.783 & 8.895 & 8.857 & 8.820 & 8.783 \\
\hline Salt & 0.483 & 0.447 & 0.411 & 0.376 & 0.483 & 0.447 & 0.411 & 0.376 \\
\hline DL-Methionine 99\% & 0.197 & 0.185 & 0.176 & 0.163 & 0.197 & 0.185 & 0.176 & 0.163 \\
\hline L-Lysine HCI 99\% & 0.000 & 0.045 & 0.124 & 0.186 & 0.000 & 0.045 & 0.124 & 0.186 \\
\hline Vitamin premix $^{1}$ & 0.100 & 0.100 & 0.100 & 0.100 & 0.100 & 0.100 & 0.100 & 0.100 \\
\hline Mineral premix ${ }^{2}$ & 0.050 & 0.050 & 0.050 & 0.050 & 0.050 & 0.050 & 0.050 & 0.050 \\
\hline Choline chloride $60 \%$ & 0.100 & 0.100 & 0.100 & 0.100 & 0.100 & 0.100 & 0.100 & 0.100 \\
\hline Anticoccidial (salinomycin 12\%) & 0.060 & 0.060 & 0.060 & 0.060 & 0.060 & 0.060 & 0.060 & 0.060 \\
\hline Antioxidant $^{3}$ & 0.010 & 0.010 & 0.010 & 0.010 & 0.010 & 0.010 & 0.010 & 0.010 \\
\hline Enzyme complex & 0.000 & 0.000 & 0.000 & 0.000 & 0.005 & 0.005 & 0.005 & 0.005 \\
\hline \multicolumn{9}{|c|}{ Calculated composition } \\
\hline Metabolizable energy, kcal/kg & 2,850 & 2,850 & 2,850 & 2,850 & 2,900 & 2,900 & 2,900 & 2,900 \\
\hline Crude protein, \% & 16.2 & 16.2 & 16.2 & 16.2 & 16.5 & 16.5 & 16.5 & 16.5 \\
\hline Digestible lysine, \% & 0.747 & 0.733 & 0.740 & 0.744 & 0.755 & 0.741 & 0.747 & 0.752 \\
\hline Digestible methionine, \% & 0.434 & 0.433 & 0.434 & 0.433 & 0.437 & 0.437 & 0.438 & 0.437 \\
\hline Digestible methionine + cystine, \% & 0.668 & 0.668 & 0.668 & 0.668 & 0.674 & 0.674 & 0.674 & 0.674 \\
\hline Digestible threonine, \% & 0.548 & 0.540 & 0.528 & 0.522 & 0.554 & 0.546 & 0.534 & 0.528 \\
\hline Digestible tryptophan, \% & 0.173 & 0.175 & 0.176 & 0.180 & 0.175 & 0.178 & 0.179 & 0.182 \\
\hline Glycine+serine, \% & 1.455 & 1.475 & 1.484 & 1.511 & 1.455 & 1.475 & 1.484 & 1.511 \\
\hline Digestible valine, \% & 0.685 & 0.690 & 0.690 & 0.698 & 0.685 & 0.690 & 0.690 & 0.698 \\
\hline Digestible isoleucine, \% & 0.626 & 0.623 & 0.615 & 0.615 & 0.626 & 0.623 & 0.615 & 0.615 \\
\hline Digestible arginine, \% & 1.007 & 1.034 & 1.062 & 1.103 & 1.007 & 1.034 & 1.062 & 1.103 \\
\hline Digestible phenylalanine + tyrosine, $\%$ & 1.259 & 1.264 & 1.260 & 1.270 & 1.259 & 1.264 & 1.260 & 1.270 \\
\hline Digestible histidine, \% & 0.418 & 0.412 & 0.403 & 0.398 & 0.418 & 0.412 & 0.403 & 0.398 \\
\hline Linoleic acid, \% & 1.473 & 3.193 & 3.776 & 4.406 & 1.473 & 3.193 & 3.776 & 4.406 \\
\hline Calcium, \% & 3.820 & 3.820 & 3.820 & 3.820 & 3.820 & 3.820 & 3.820 & 3.820 \\
\hline Available phosphorus, \% & 0.341 & 0.341 & 0.341 & 0.341 & 0.341 & 0.341 & 0.341 & 0.341 \\
\hline Sodium, \% & 0.209 & 0.209 & 0.209 & 0.209 & 0.209 & 0.209 & 0.209 & 0.209 \\
\hline Crude fiber, \% & 2.389 & 3.892 & 5.385 & 6.895 & 2.389 & 3.892 & 5.385 & 6.895 \\
\hline Neutral detergent fiber, \% & 10.698 & 13.152 & 15.604 & 18.056 & 10.698 & 13.152 & 15.604 & 18.056 \\
\hline Acid detergent fiber, \% & 4,185 & 5,407 & 6,617 & 7,846 & 4,185 & 5,407 & 6,617 & 7,846 \\
\hline
\end{tabular}

${ }^{1}$ Vitamin supplement (kg of product): vit. A - 10,000,000 IU; vit. D3 - 2,000,000 IU; vit. E - 30,000 IU A; vit. B1 - 2.0 g; vit. B2 - 6.0 g; vit. B6 - 4.0 g; vit. B12 - 0.015 g; pantothenic acid - $12.0 \mathrm{~g}$; biotin - $0.1 \mathrm{~g}$; vit. K3 - $3.0 \mathrm{~g}$; folic acid - $1.0 \mathrm{~g}$; nicotinic acid $-50.0 \mathrm{~g}$; Se $-250.0 \mathrm{mg}$.

${ }^{2}$ Mineral supplement (kg of product): Fe - $80 \mathrm{~g} ; \mathrm{Cu}-10 \mathrm{~g} ; \mathrm{Co}-2 \mathrm{~g} ; \mathrm{Mn}-80 \mathrm{~g} ; \mathrm{Zn}-50 \mathrm{~g} ; \mathrm{I}-1 \mathrm{~g}$.

${ }^{3}$ Antioxidant: BHT (Butylated hydroxytoluene). 
Table 2 - Nutritional values attributed to the enzyme complex

\begin{tabular}{llc}
\hline Nutritional matrix & Per kg & Added with inclusion \\
\hline Metabolizable energy, kcal/kg & $1,000,000$ & 50 \\
\hline Crude protein, \% & 7,200 & 0.360 \\
\hline Digestible lysine, \% & 150 & 0.008 \\
\hline Digestible methionine, \% & 70 & 0.004 \\
\hline Methionine + digestible cystine, \% & 120 & 0.006 \\
\hline Digestible threonine, \% & 120 & 0.006 \\
\hline Digestible tryptophan, \% & 35 & 0.002 \\
\hline Digestible arginine, \% & 170 & 0.009 \\
\hline Enzyme complex content (\%) & & \\
\hline Endo-1,3(4)-beta-glucanase & 14.0 & \\
\hline Xylanase & 11.0 & \\
\hline 6-Phytase & 5.0 & \\
\hline Inert & 70.0 & \\
\hline Rovabio Excel AP &
\end{tabular}

Table 3 - Chemical composition of sunflower meal

\begin{tabular}{|c|c|}
\hline Sunflower meal dry matter $^{1}$ & 91.37 \\
\hline Metabolizable energy, $\mathrm{kcal} / \mathrm{kg}^{2}$ & 1,983 \\
\hline Crude protein, $\%^{1}$ & 25.00 \\
\hline Digestible lysine, $\%^{2}$ & 0.634 \\
\hline Digestible methionine, $\%^{2}$ & 0.504 \\
\hline Methionine + cystine, $\%^{2}$ & 0.858 \\
\hline Digestible threonine, $\%^{2}$ & 0.765 \\
\hline Digestible tryptophan, $\%^{2}$ & 0.315 \\
\hline Total glycine + serine, $\%^{2}$ & 2.560 \\
\hline Digestible valine, $\%^{2}$ & 1.140 \\
\hline Digestible isoleucine, $\%^{2}$ & 0.970 \\
\hline Digestible arginine, $\%^{2}$ & 2.080 \\
\hline Digestible phenylalanine + tyrosine, $\%^{2}$ & 2.050 \\
\hline Digestible histidine, $\%^{2}$ & 0.570 \\
\hline Linoleic acid, \%² & 0.600 \\
\hline Ether extract, $\%^{1}$ & 2.120 \\
\hline Mineral matter $\%^{1}$ & 4.730 \\
\hline Calcium, $\%^{1}$ & 0.140 \\
\hline Total phosphorus, $\%^{1}$ & 0.939 \\
\hline Available phosphorus, $\%^{2}$ & 0.310 \\
\hline Sodium, $\%^{2}$ & 0.200 \\
\hline Crude fiber, $\%^{1}$ & 22.37 \\
\hline Neutral detergent fiber, $\%^{1}$ & 45.19 \\
\hline Acid detergent fiber, $\%^{1}$ & 21.35 \\
\hline
\end{tabular}

'Analysis performed in the Laboratory of Animal Nutrition of UFV.

${ }^{2}$ Average values obtained from the NRC (1998), FEDNA (2003), INRA (2004), and Tavernari et al. (2010).

In order to verify the economic viability of including sunflower meal in the diet, the cost of the diet was determined in Brazilian real $(R \$)$ per dozen of eggs produced and per kilogram of eggs produced (Yi). The equation was adapted from the methodology of
Bellaver et al. (1985): Yi $=(\mathrm{Pi}$ * Qi) / Ei, where $\mathrm{Yi}=$ diet cost per dozen of eggs produced and per kilogram of eggs produced in the i-th treatment (sunflower meal level); $\mathrm{Pi}=$ price per kilogram of the diet utilized in the i-th treatment; Qi, quantity of diet consumed in the i-th treatment; and $\mathrm{Ei}=$ dozen of eggs produced and kilogram of eggs produced. Next, the economic efficiency index (EEI) was calculated: $\mathrm{EEI}=(\mathrm{LCe} / \mathrm{CTei})$ * 100 , where $\mathrm{LCe}=$ lowest cost of diet per dozen of eggs produced and kilogram of eggs produced observed between the treatments; and CTEi = cost of the $\mathrm{i}$-th treatment.

The values (price $/ \mathrm{kg}$ ) of the ingredients used to calculate the costs were those practiced in the region of Viçosa, in May 2010, as follows: butylated hydroxytoluene ( $R \$$ 6.82), limestone ( $R \$$ 0.028), choline chloride ( $R \$ 2.92)$, enzyme complex ( $R \$ 6.43)$, DL-methionine ( $R \$ 8.15)$, soybean meal ( $R \$ 0.63$ ), sunflower meal $(R \$ 0.31)$, dicalcium phosphate $(R \$$ 1.18), L-lysine ( $R \$ 4,84)$, L-threonine ( $R \$ 8.15)$, corn ( $R \$$ $0.53)$, oil ( $R \$ 2.57)$, salt $(R \$ 0.19)$, vitamin supplement for growth ( $R \$ 2.195)$, vitamin supplement ( $R \$ 3.30$ ), and mineral supplement $(R \$ 1.86)$.

Data were statistically analyzed using the PROC GLM procedure of the software $\mathrm{SAS}^{\circledR}$ (Statistical Analysis System, 2002) was employed in a factorial arrangement, adopting $5 \%$ as significance level. Initial live weight was utilized as co-variable for the performance of the ANOVA. Linear and quadratic functions were utilized for the determination of the ideal level of sunflower meal, and the Student-Newmann-Keul test was used for the evaluation of enzyme complex inclusion.

\section{RESULTS AND DISCUSSION}

Mean temperatures recorded during the experiment were $20.5{ }^{\circ} \mathrm{C}$ (15.2 and $25.7{ }^{\circ} \mathrm{C}$ minimum and maximum, respectively). No interaction was verified between EC inclusion and sunflower meal levels $(p<0.05$; Tables 3 to 10). Junqueira.et al. (2010) also did not verify any effects of the interaction between sunflower meal and the addition of phytase in the layer diets on most production parameters, except for egg mass.

During the evaluation period, egg production and feed conversion ratio per egg mass (GCRdz) were affected by sunflower meal (SFM) levels $(p<0.05$; Table 4), as described by the following equations: EP = $89.845+0.0994$ SFM -0.0074 SFM $^{2}\left(R^{2}=98.0\right)$, with maximum point at the $6.72 \%$ inclusion level; FCRdz $=$ $1.6525-0.0035$ SFM +0.0003 SFM $^{2}\left(R^{2}=98.8\right)$, with 
minimum point at $5.83 \%$ inclusion level . These results are considerably different from the findings of Vieira et al. (1992), who reported that dietary sunflower meal levels up to $40.5 \%$ did not affect layer performance. However, current commercial layer strains are more nutrient-demanding (Hy Line, 2009), and therefore, high levels of SFM in the diet would compromise their performance. Other authors have also reported the inclusion of high SFM levels $(20.0 \%)$ in commercial layer diets (Senkoylu et al., 2004). However, the sunflower meal utilized in the diets were submitted only to partial oil extraction, and therefore nutritional value was much higher than that of the SFM utilized in the present study. Most of the results reported in the literature recommend the utilization of SFM levels close to those included here (Tsuzuki et al., 2003; Casartelli et al., 2006; Rezaei \& Hafezian 2007; Junqueira et al., 2010).

Table 4 - Feed intake, egg production, egg weight, egg mass, and feed conversion ratio per dozen eggs and per egg mass in 64- to 79-week-old layers fed diets with increasing sunflower meal (SFM) levels and supplemented or not with an enzyme complex (EC)

\begin{tabular}{|c|c|c|c|c|c|}
\hline & \multicolumn{4}{|c|}{ Sunflower meal levels } & \\
\hline & $0 \%$ & $8 \%$ & $16 \%$ & $24 \%$ & \\
\hline & \multicolumn{4}{|c|}{ Feed intake (g) } & Mean \\
\hline With EC & 105 & 105 & 105 & 109 & 106 \\
\hline Without EC & 109 & 107 & 112 & 110 & 110 \\
\hline Mean & 107 & 106 & 108 & 109 & \\
\hline ANOVA & Treat $=0.8239^{\text {ns }}$ & $\mathrm{SM}^{\beta}=0.3537^{\mathrm{ns}}$ & Trea & $84^{\text {ns }}$ & $C V(\%)=5.59$ \\
\hline \multirow[t]{2}{*}{ Probability } & - & NS & & & \\
\hline & \multicolumn{4}{|c|}{ Egg production (\%) } & \\
\hline With EC & 89.6 & 89.6 & 88.8 & 88.3 & 89.1 \\
\hline Without EC & 90.2 & 90.2 & 90.5 & 87.3 & 89.5 \\
\hline Mean & 89.9 & 90.0 & 89.7 & 87.8 & \\
\hline ANOVA & $\mathrm{EC}=0.3436^{\mathrm{ns}}$ & $S F M=0.0365^{*}$ & EC & $81^{\text {ns }}$ & $C V(\%)=4.19$ \\
\hline \multirow[t]{2}{*}{ Probability } & - & $\mathrm{Q}$ & & & \\
\hline & \multicolumn{4}{|c|}{ Egg weight (g) } & \\
\hline With EC & 64.2 & 65.2 & 64.6 & 65.9 & 65.0 \\
\hline Without EC & 67.0 & 64.5 & 66.3 & 67.5 & 66.3 \\
\hline Mean & 65.6 & 64.9 & 65.4 & 66.7 & \\
\hline ANOVA & $\mathrm{EC}=0.3640^{\mathrm{ns}}$ & SFM $=0.6561^{\mathrm{ns}}$ & EC & $85^{\text {ns }}$ & $C V(\%)=4.32$ \\
\hline \multirow[t]{2}{*}{ Probability } & - & NS & & & \\
\hline & \multicolumn{4}{|c|}{ Egg mass (g) } & Mean \\
\hline With EC & 57.5 & 58.4 & 57.4 & 58.2 & 57.9 \\
\hline Without EC & 60.4 & 58.2 & 60.0 & 58.9 & 59.3 \\
\hline Mean & 59.0 & 58.4 & 58.7 & 58.6 & \\
\hline ANOVA & $\mathrm{EC}=0.1676^{\mathrm{ns}}$ & $\mathrm{SFM}=0.3734^{\mathrm{ns}}$ & $\mathrm{EC}$ & $23^{\text {ns }}$ & $C V(\%)=5.88$ \\
\hline \multirow[t]{2}{*}{ Probability } & - & NS & & & \\
\hline & \multicolumn{4}{|c|}{ Feed conversion ratio per dozen eggs (kg/dozen) } & \\
\hline With EC & 1.49 & 1.49 & 1.51 & 1.57 & 1.52 \\
\hline Without EC & 1.54 & 1.51 & 1.57 & 1.61 & 1.56 \\
\hline Mean & 1.52 & 1.50 & 1.54 & 1.59 & \\
\hline ANOVA & $\mathrm{EC}=0.8686^{\mathrm{ns}}$ & $\mathrm{SFM}=0.0150^{*}$ & EC & $12^{\mathrm{ns}}$ & $C V(\%)=5.82$ \\
\hline \multirow[t]{2}{*}{ Probability } & - & Q & & & \\
\hline & \multicolumn{4}{|c|}{ Feed conversion ratio per egg mass $(\mathrm{kg} / \mathrm{kg})$} & \\
\hline With EC & 1.94 & 1.90 & 1.96 & 1.99 & 1.95 \\
\hline Without EC & 1.93 & 1.96 & 1.97 & 1.98 & 1.96 \\
\hline Mean & 1.94 & 1.93 & 1.97 & 1.99 & \\
\hline ANOVA & $\mathrm{EC}=0.1788^{\text {ns }}$ & SFM $=0.0579^{\text {ns }}$ & EC & $51^{\text {ns }}$ & $C V(\%)=6.42$ \\
\hline Probability & - & NS & & & \\
\hline
\end{tabular}

EC - enzyme complex addition; CV - coefficient of variation; $\beta$ FG (\%) - percentage of sunflower meal in the diet; $\gamma$ - Interaction between the presence of EC and SFM (\%): ${ }^{\text {s }}$ - not significant by the F test ( $p>0.05) ;{ }^{*}$ - significantly different by the F test $(p<0.05)$; Q - quadratic effect $(p \leq 0.05)$ of sunflower meal level; $L$ - linear effect $(p \leq 0.05)$ of sunflower meal level; NS/ns - non-significant effect. 


\section{Sunflower Meal and Supplementation of an Enzyme Complex in Layer Diets}

Feed intake, egg mass, egg weight, and feed conversion ratio per egg mass were not influenced by the treatments ( $p>0.05$; Table 4). Secoylu et al. (2004) did not find any differences in these parameters either, when including up to $20.0 \%$ sunflower meal in the diets of commercial strains. On the other hand, Casartelli et al. (2006) reported that the dietary inclusion of $12.0 \%$ sunflower meal did not affect layer feed intake or egg mass. Similar results were found with when up to $10.0 \%$ sunflower meal was included in layer diets containing equal energy and protein levels (Rezaei \& Hafezian, 2007).
During the evaluation period, egg components were not affected by the treatments ( $p>0.05$; Table $5)$. These results are consistent with those reported in literature (Tsuzuki et al., 2003; Secoylu et al., 2004; Rezaei \& Hafezian, 2007). Only Casartelli et al. (2006) showed an improvement in eggshell parameter as a function of increasing sunflower meal inclusion levels in the diet of commercial layers. In spite of the positive result reported by these authors, it is not likely that the dietary sunflower meal inclusions result in eggshell improvement, because this feedstuff is not very rich in nutrients and has high fiber content.

Table 5 - Yolk weight, albumen weight, eggshell weight, and weight gain 64- to 79-week-old layers fed diets with increasing sunflower meal (SFM) levels and supplemented or not with an enzyme complex (EC)

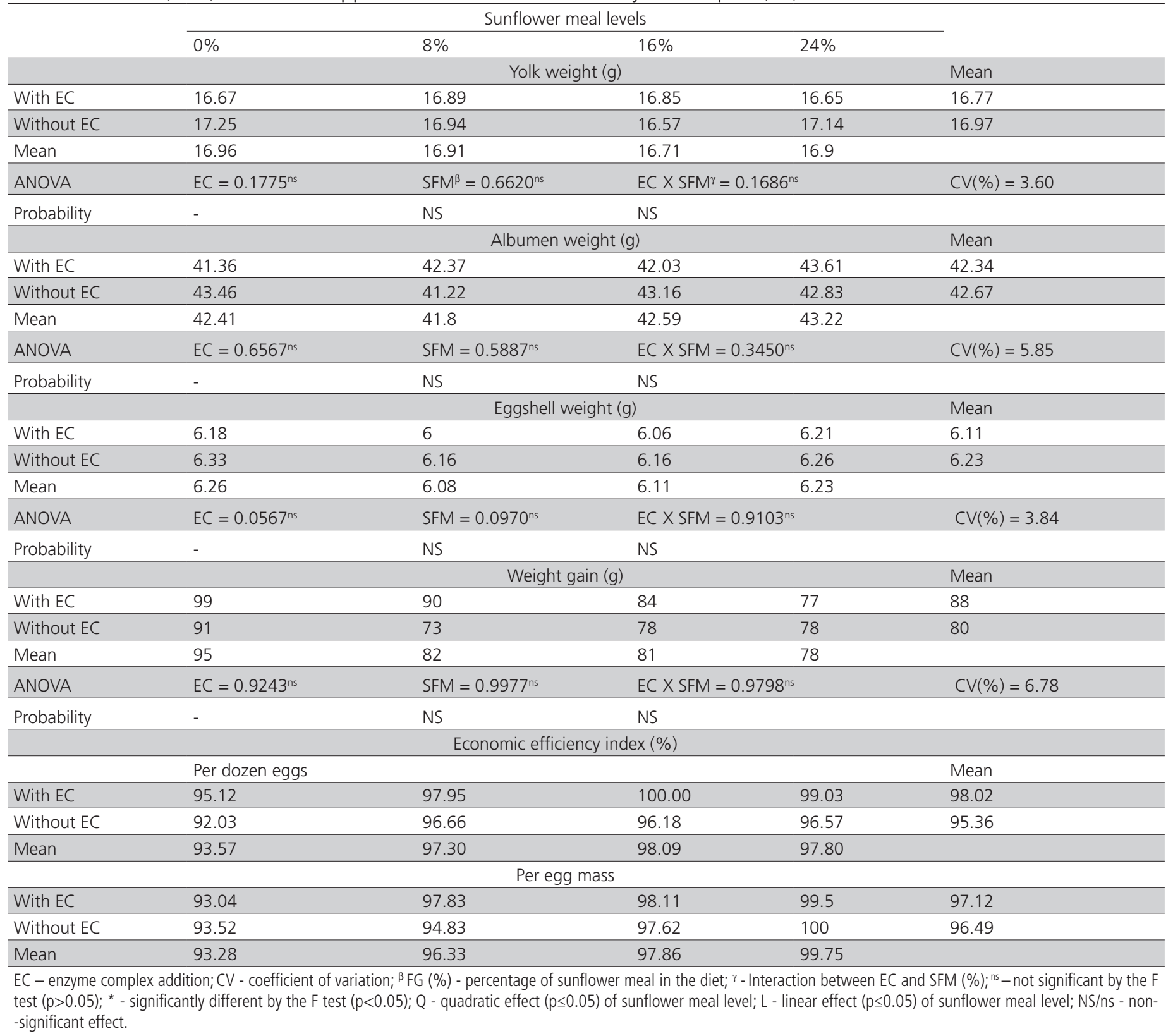


The best economic efficiency per dozen eggs and per egg mass was obtained with the diet containing $16.0 \%$ sunflower meal and supplemented with the enzyme complex, and with the diet with $24 \%$ sunflower meal and not supplemented with the enzyme complex, respectively. These results are contradictory A similar situation was also verified by Junqueira et al. (2010), who obtained better economic efficiency on diets with $4.0 \%$ sunflower meal and the addition of phytase. As it is an alternative feedstuff, its economic efficiency is essentially to its low price relative to typical feedstuffs (corn and soybean meal). This feedstuff tends to become increasingly cheaper because the sunflower crop is expanding in Brazil. However, the present results are consistent with current prices, and therefore, future studies estimating the economic viability of the utilization of this feedstuff in commercial layer diets are warranted.

The inclusion of the enzyme complex in layer diets did not affect their performance or egg components ( $p>0.05$; Tables 4 and 5). These results are different from the findings of Junqueira et al. (2010), who found better efficiency of phytase added to layer diets, as shown by the higher egg mass obtained with $8 \%$ sunflower meal inclusion and the addition of phytase in comparison with $4.0 \%$ SFM and no phytase inclusion. Bess et al. (2006) did not observed any significant differences in the utilization of phytase in broiler breeder diets, using an experimental design very similar to that applied in the present study. Sunflower meal is rich in fiber and phytic acid, and therefore, a positive effect with the addition of the enzyme complex in the diets was expected; however, no such effect was verified in the present experiment.

Liu et al. (2007) and Viana et al. (2009) also verified that the addition of phytase to diets with reduced nutrient levels did not improve egg production, egg weight, or feed conversion per dozen eggs of layers. The results of these authors were very similar to those found in the present study, where no influence of enzyme complex on those parameters were detected.

There was no interaction between the dietary addition of enzyme complex and sunflower meal levels ( $p>0.05)$. The addition of the enzyme complex in the diets did not affect egg-production parameters or egg components $(p>0.05)$. Increasing dietary SFM levels had a quadratic effect on egg production and feed conversion ratio per dozen eggs $(P<0.05)$, with ideal points of sunflower meal inclusion of 6.72 and $5.83 \%$, respectively. The best economic efficiency per dozen eggs and per egg mass was obtained with the diet containing $16.0 \%$ sunflower meal and supplemented with the enzyme complex, and with the diet with $24 \%$ sunflower meal and not supplemented with the enzyme complex, respectively

\section{CONCLUSIONS}

The addition of the evaluated enzyme complex in layer diets does not improve egg-production parameters or egg components. Dietary sunflower meal levels of 6.72 and $5.83 \%$, promote the best egg production and feed conversion ratio per dozen eggs. The inclusion of sunflower meal in layer diets improves the economic efficiency index per dozen eggs and per egg mass provided feedstuff prices are similar to those applied in the present study.

\section{ACKNOWLEDGEMENTS}

We are grateful to the Research Support Foundation of the State of Minas Gerais (FAPEMIG) for their support.

\section{REFERENCES}

Bellaver C, Fialho ET, Protas JFS. Radícula de malte na alimentação de suínos em crescimento e terminação. Pesquisa Agropecuária Brasileira 1985;20(8): 969-974.

Bess F, Rosa AP, Krabbe EP. Efeito da adição de fitase sobre a porcentagem de postura e densidade de ovos em matrizes de corte. Brazilian Journal of Poultry Science 2006;8:106.

Casartelli EM, Filardi RS, Junqueira OM. Sunflower meal in commercial layer diets formulated on total and digestible amino acids basis. Brazilian Journal of Poultry Science 2006;8(3): 167-171.

FEDNA- Fundacíon Española para el Desarrollo de la Nutrición Animal. Tablas de composición y valor nutritivo de alimentos para la fabricación de piensos compuestos. $2^{\text {nd }}$ ed. Madrid: Ediciones Mundi Prensa; 2003.

Liu N, Liu GH, Li FD. Efficacy of phytases on egg production and nutrient digestibility in layers fed reduced phosphorus diets. Poultry Science 2007;86(11):2337-2342.

NRC- National Research Council. Nutrient requirements of poultry. $9^{\text {th }}$ ed Washington: National Research Council; 1994. 155p.

Hy Line. Manual da variedade Brown. Uberlândia; 2009.

Junqueira OM, Filardi RS, Ligeiro EC. Avaliação técnica e econômica da matriz nutricional da enzima fitase em rações contendo farelo de girassol para poedeiras comerciais. Revista Brasileira de Zootecnia 2010;39(10):2200-2206.

Rostagno HS, Albino LFT, Donzele JL. Tabelas brasileiras para aves e suínos: composição de alimentos e exigências nutricionais. Viçosa: Universidade Federal de Viçosa; 2005.

Rezaei M, Hafezian H. Use of different levels of high fiber sunflower meal in commercial leghorn type layer diets. International Journal of Poultry Science 2007;6(6):431-433. 
SAS Institute. User guide for personal computer. Cary; 2002.

Sauvant D, Perez JM, Tran G. Tablas de composición y de valor nutritivo de las materias primas destinadas a los animales de interés ganadero: cerdos, aves, bovinos, ovinos, caprinos, conejos, caballos, peces. $2^{\text {nd }}$ ed. Madrid: Institute National de la Recherche Agronomique, Ediciones Mundi Prensa; 2004. p.194-197.

Senkoylu N, Akyurek H, Samli HE. The possibilities of using high oilsunflower meal and enzyme mixture in layer diets. Pakistan Journal of Nutrition 2004;3(5):285-289.

Serman V, Mas N, Melenjuk V. Use of sunflower meal in feed mixtures for laying hens. Acta Veterinaria Brunensis 1997;66(4):219-227.
Tavernari FC, Morata RL, Ribeiro Jr V. Avaliação nutricional e energética do farelo de girassol para aves. Arquivos Brasileiros de Medicina Veterinária e Zootecnia 2010;62(1):172-177.

Tsuzuki ET, Garcia ERM, Murakami AE. Utilization of sunflower seed in laying hen rations. Brazilian Journal of Poultry Science 2003;5(3):179182

Viana MTS, Albino LFT, Rostagno HS. Efeito da suplementação de enzima fitase sobre o metabolismo de nutrientes e o desempenho de poedeiras. Revista Brasileira de Zootecnia 2009; 38(6):1074-1080.

Vieira SL, Penz JR, AM, Leboute EM. A nutritional evaluation of a high fiber sunflower meal. Journal Applied of Poultry Science 1992;1:382-388. 